\section{In Vitro Multiple Bud Formation by 20-year-old Western Larch Buds and Stems}

\author{
E.E. Chesick ${ }^{1}$, D.E. Bilderback, and G.M. Blake \\ School of Forestry and Department of Botany, University of Montana, \\ Missoula, MT 59812
}

\begin{abstract}
Additional index words. mature tissue, 6-benzyladenine, tissue culture, Larix occidentalis
\end{abstract}

\begin{abstract}
Vegetative long-shoot buds, greenwood stems, and immature needles of 20year-old western larch (Larix occidentalis Nutt.) were cultured to induce multiple bud formation. Explants were collected year-round and cultured on a modified Schenk and Hildebrandt (SH) medium containing 6-benzyladenine $(\mathrm{BA})$ at $0,1,5,10,50$, or 100 $\mu \mathrm{M}$. Multiple buds were produced on buds and stems with terminal meristems, but not on needles or stem sections. The induction of de novo buds and development of axillary buds required $\mathrm{BA}$ at 1 to $10 \mu \mathrm{M}$; higher concentrations of $\mathrm{BA}$ were less effective. More explants formed multiple buds on SH than on modified Murashige and Skoog (MS) media. Multiple buds formed on more buds and stems excised during the growing season than from dormant buds. Buds cultured on media containing gibberellin died within 6 weeks; auxin caused bud elongation but no multiple buds formed. Chemical names used: $\mathrm{N}$-[(trichloromethyl)thio]-4-cyclohexene-1,2-dicarboximide (captan); 6-benzyladenine (BA); 1H-indole-3-butyric acid (IBA); 1H-indole-3-acetic acid (IAA); gibberellin $\left(\mathbf{G A}_{4+7}\right)$.
\end{abstract}

Plantlets have been derived from embryonic tissues cultured in vitro from numerous conifer species (2). Few conifer species have been induced to form multiple buds from tissues of mature trees (2). Multiple adventitious bud formation has been reported on explants from mature Siberian and Dahurian larches (6), and buds and plantlets have been reported from vegetative buds, female strobili, and callus cultures of mature European larch (1-5). However, to the best of our knowledge, induction of buds has not been reported from mature western larch (Larix occidentalis Nutt.), an economically important tree species in the northern Rocky Mountains. The objective of this study was to test the effects of growth stage, growth regulators, and two media on multiple bud formation from long-shoot buds, stems, and needles of mature western larch trees.

Western larch tissue was collected from 20-year-old trees in western Montana. Longshoot buds, which become stems, were harvested from lower lateral branches and stored in plastic bags at $5 \mathrm{C}$ for up to 2 weeks. Buds were collected from August to mid-April and

Received for publication 31 Oct. 1988. This research was supported by a McIntire-Stennis grant at the Univ. of Montana. Thanks to the USDA Forest Service at Moscow, Idaho, for the loan of the growth chambers and to Carl Mohn of the Univ. of Minnesota for assistance with statistical analysts of data. The cost of publishing this paper was defrayed in part by the payment of page charges. Under postal regulations, this paper therefore must be hereby marked advertisement solely to indicate this fact.

${ }^{1}$ Current address: Westvaco Corporation, Forest Science Laboratory, P.O. Box 1950, Summerville, SC 29484.
All media contained 3\% sucrose, $0.45 \%$ to $0.5 \%$ Difco Bacto-agar, and the SH vitamins. Media were adjusted to $\mathrm{pH} 5.5$ before adding agar and autoclaved for $20 \mathrm{~min}$ at 1.1 $\mathrm{kg} \cdot \mathrm{cm}^{-2}$.

With SH medium, six BA concentrations were tested for bud induction at each tissue sampling date, but $5 \mu \mathrm{M}$ BA was used in all subsequent treatments. Three concentrations of MS medium were tested: full, half, and full with one-quarter of the nitrate component (9). Buds were also cultured on $\mathrm{SH}$ medium containing 10,1 , or $0.1 \mu \mathrm{M}$ GA alone or with $5 \mu \mathrm{M}$ BA. The auxins, IBA and IAA, were tested at the same concentrations and combinations as the GA. Twenty larch buds were placed on each of the 18 different media for a total of 360 buds.

Explants were transferred after 6 to 8 weeks on the bud-induction medium to half-strength SH medium, with no growth regulators for shoot elongation. All multiple buds $>5 \mathrm{~mm}$ in height were excised and placed individually in culture.

Cultures were grown in a growth chamber at $25 \mathrm{C}$ with $24 \mathrm{hr}$ of continuous mixed fluorescent-incandescent light with a light intensity of $30 \mathrm{mmol} \cdot \mathrm{s}^{-1} \cdot \mathrm{m}^{-2}$.

The data were analyzed using $x^{2}$ and Friedman's nonparametric tests.

When BA was included in the SH medium, larch buds and stems with meristems formed multiple buds (Figs. 2 and 3). All concentrations were effective, although slightly fewer explants responded on media containing the higher BA concentrations of 50 or $100 \mu \mathrm{M}(3 \%$ vs. $5 \%)$. BA at concentrations $>1 \mu \mathrm{M}$ inhibited internode and needle elongation of excised buds. On medium lacking BA, internodal tissue and needle primordia elongated, but no multiple buds formed. There was a significant difference in bud formation between treatments lacking and containing BA (0\% vs. $4 \%)$. BA and collection date were found to be independent. No multiple buds formed on needles, needle segments, or stem segments.

Within any single BA treatment, response varied from tissue death to multiple bud formation and callus growth. The number of buds formed per responding explant was

Table 1. Proportion of terminal larch stem pieces forming multiple buds as a function of medium and collection date. All media contained $5 \mu \mathrm{M}$ BA. Cultures initiated on 14 Apr. and 11 July did not produce buds.

\begin{tabular}{llcccc}
\hline \hline & \multicolumn{5}{c}{ Collection date $^{\mathbf{z}}$} \\
\cline { 2 - 4 } \multicolumn{1}{c}{ Medium } & 22 May & 18 June & 27 June & Mcan & $\chi^{2 y}$ \\
\hline MS & 0.00 & $0.06(7)$ & 0.00 & $0.03(7)$ & 4.97 \\
1/2 MS & $0.07(42)$ & $0.11(13)$ & 0.00 & $0.08(22)$ & 0.73 \\
1/4N MS & $0.04(12)^{\mathbf{x}}$ & $0.17(11)$ & $0.05(13)$ & $0.12(12)$ & 0.03 \\
SH & $0.29(16)$ & $0.23(6)$ & $0.03(9)^{\mathbf{x}}$ & $0.23(11)$ & 8.50 \\
Mean & $0.10(20)$ & $0.14(9)$ & $0.02(12)$ & $0.12(13)$ & \\
Buds/treatment & 28 & 35 & 38 & & \\
Chi-square $^{w}$ & 0.01 & 6.63 & 6.12 & & \\
\hline
\end{tabular}

${ }^{2}$ Average shoot number/explant responding in parentheses.

${ }^{\mathrm{y}}$ Chi-square statistic: $x^{2}=14.23$, and $P=0.003$, indicating significant differences between media. ${ }^{\mathrm{x}}$ Number of shoots from only one bud.

${ }^{\mathrm{w}}$ Chi-square statistic: $x^{2}=12.76$, and $P=0.003$, indicating significant differences between collection dates. 


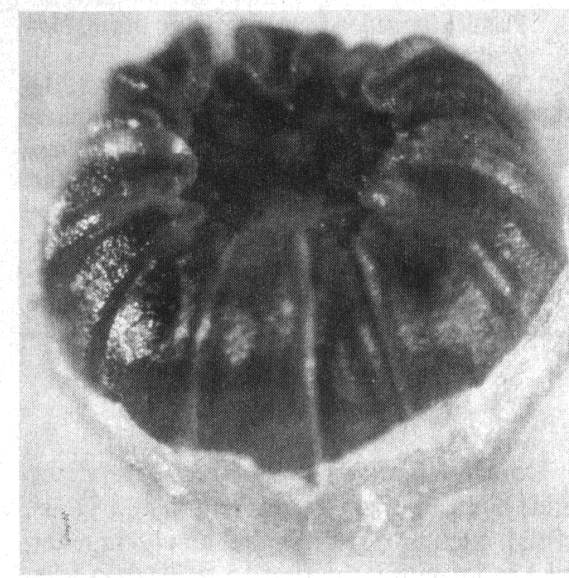

Fig. 1. Excised western larch bud prior to culturing, $\approx 2 \mathrm{~mm}$ in diameter.

highly variable, from one to 23 per responding bud, with an average of seven, and from one to 78 per stem section, with an average of 11 ; one stem section produced 48 buds and another 78. Because of this variability, only data on proportion of responding explants were analyzed. By the time the new buds were visible, the original morphology was often completely altered, and it was difficult to determine if the induced buds were axillary or adventitious.

Of the stem sections with or without a terminal meristem, only those with a terminal meristem survived in culture. They increased in diameter and the entire terminal stem segment was transformed into multiple buds. Stem pieces produced both axillary and adventitious buds. Buds formed in needle axils above needle scars; when more than one formed in a needle axil, we assumed that some of the buds were adventitious.

Multiple buds formed at a more rapid rate from buds and stems collected during June than from tissues collected at other times of the year, and more explants responded than at other times of the year. In the June experiments, 3 to 6 weeks elapsed before multiple buds appeared on cultured stems, but, at other times, 3 to 4 months were required. There was a significant difference in number of stems responding according to time of collection (Table 1).

Of the different media tested using stems, the lowest proportion of responding explants occurred on full-strength MS, whereas SH medium produced the highest proportion of multiple buds (Table 1), and the difference was significant at $P=0.05$. Medium and collection time were found to be independent.

Multiple buds usually elongated when transferred to elongation medium. Occasionally, multiple buds appeared after the tissue had been on the medium for 2 weeks.

Gibberellin $\left(\mathrm{GA}_{4+7}\right)$ did not stimulate multiple bud formation. Only slight enlargement of the original 2-mm buds occurred and all died in $<6$ weeks.

When auxin (IAA or IBA) was added to media lacking BA, the excised buds elongated, but did not form multiple buds. In 6

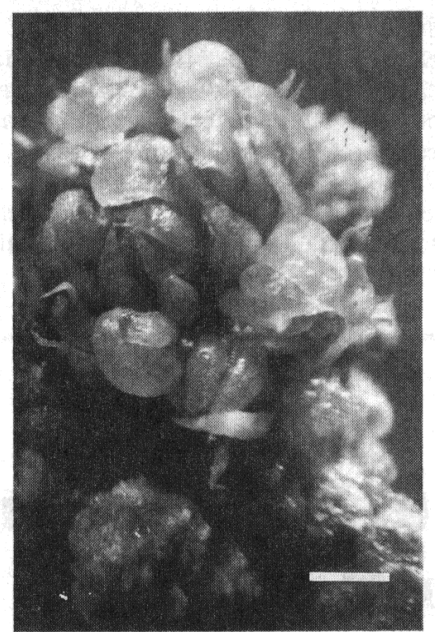

Fig. 2. New developing buds on a larch bud. Cultured on $\mathrm{SH}$ medium with $10 \mu \mathrm{M}$ BA. Scale bar $=1 \mathrm{~mm}$.

weeks, needles and stems elongated from the original $2 \mathrm{~mm}$ to 7 to $10 \mathrm{~mm}$, and a green, slow-growing callus formed at the base of the bud. When BA was included with auxin, shoot elongation and adventitious bud formation were absent and callus grew quickly from the lower edges of the buds, engulfed the needles, and rapidly turned brown. More callus was produced on media containing auxin and BA than on media containing only auxin. There was no apparent difference between auxins or auxin concentrations.

Full-strength SH medium supplemented with $5 \mu \mathrm{M} \mathrm{BA}$ was the most effective treatment for inducing multiple bud formation. Succulent stem segments with the terminal meristem, collected during late May through late June, responded best in culture, both in the number of explants responding and speed of response. SH medium, which contained the lowest level of nitrate, induced the most explants to produce multiple buds.

The presence of BA was required for multiple bud formation. Inclusion of other plant growth regulators did not enhance multiple bud formation; however, auxins stimulated elongation of dormant buds and could be effective in enhancing the elongation of induced buds.

The BA concentrations most effective in this study were similar to those used by Momot and Smirnov (6) with mature $L$. dahurica and L. siberica. Shoot, callus, and adventitious bud formation were induced from stem apices cultured on MS medium containing 5 to $15 \mu \mathrm{M} \mathrm{BA}$; auxin alone or auxin plus cytokinin stimulated shoot elongation. Similar responses were found with western larch cultures in this study. Bonga $(1,3,4)$ induced callus and shoot formation, and shoots from callus, from both vegetative buds and female strobili of European larch $(L$. decidua) when cultured on medium containing $50 \mu \mathrm{M}$ BA $(3,4)$ or $10 \mu \mathrm{M}$ BA(1). Plantlets from mature European larch were also produced (1). Laliberté and Lalonde (5) produced plantlets from callus when buds from a 12-year-old Larix xeuroleptis tree were

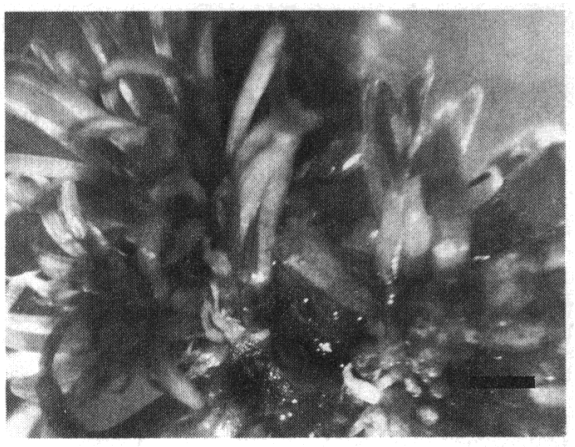

Fig. 3. Multiple buds developing on a larch bud cultured on $\mathrm{SH}$ medium with $10 \mu \mathrm{M}$ BA after 3 weeks on elongation medium. Scale bar $=1$ $\mathrm{m} \mathrm{m}$

cultured on medium containing 0.2 to $10 \mu \mathrm{M}$ BA with or without $1 \mu \mathrm{M}$ IBA. In this study, western larch produced both shoots and callus, but shoots were not determined to have developed from the callus.

In Bonga's work with European larch, seasonal effects were also noted. Predormant, late-growing-season $(3,4)$, and prebudbreak (March) (1) vegetative materials responded better than the succulent materials that responded best with western larch in our study. Bonga $(1,3)$ also found that only sections from female cones collected at the time of meiosis, early in the growing season, produced shoots. Lalibertt and Lalonde (5) found their most productive calli were induced from materials collected in June and August.

Western larch and European larch have long shoot buds that are not entirely preformed. While new bud and some needle initiation occurs during late August and early September, lateral buds and half the stem needles are produced after dormancy (7). This may account for the improved response observed in June with western larch and European larch callus (6), and the response in March, August, and September with European larch $(1,3,4)$.

Inducing multiple buds on vegetative buds or stems from mature larch trees is the first step in vegetatively propagating phenotypically desirable trees by tissue culture. Furthe; work is needed to-increase the numbers of buds per explant, reliably produce buds, elongate buds into shoots, and root them.

\section{Literature Cited}

1. Bonga, J.M. and P. von Aderkas. 1988. Attempts to micropropagate mature Larix decidua Mill, p. 155-168. In: M.R. Ahuja (ed.). Somatic cell genetics of woody plants. Kluwer Academic, Dordrecht, Netherlands.

2. Bonga, J.M. and D.J. Durzan. 1987. Cell and tissue culture in forestry. vol. 3. Martinus Nijhoff, Dordrecht, Netherlands.

3. Bonga, J.M. 1984. Adventitious shoot formation in cultures of immature female strobili of Larix decidua. Physiol. Plant. 62:416-421.

4. Bonga, J.M. 1984. Adventitious shoot and root formation in tissue cultures of mature $\mathrm{La}$ $r k$ decidua. Intl. Symp. Recent Advances Forest Biotechnol. Traverse City, Mich.

5. Laliberté. S. and M. Lalonde. 1988. Sustained cakogenesis in callus cultures of Lark xeurolepsis initiated from short shoot buds 
of a 12-year-old tree. Amer. J. Bot. 75:767777.

6. Momot, T.S. and A.M. Smirnov. 1978. Organogenesis from various organs of the $\mathrm{Si}$ berian and Dahur larch (Larix sibirica Maxim. and $L$. dahurica Turcz.) and yellow pine (Pinusponderosa Dougl.) cultured in vitro. Izv. Acad. Nauk. SSSR. Ser. B. 5(6):758-761.
(Engl. trans.)

7. Owens, J.N. and M. Molder. 1979. Bud development in Larix occidentalis. 1. Growth and development of vegetative long shoot and vegetative short shoot buds. Can. J. Bot. 57(7):687-700.

8. Reilly, K. and J. Washer. 1977. Vegetative propagation of radiata pine by tissue culture:
Plantlet formation from embryonic tissue. New Zealand J. For. Sci. 7:199-206.

9. Thompson, D.G. and J.B. Zaerr. 1981. Induction of adventitious buds on cultured shoot tips of Douglas-fir (Pseudotsuga menziesii (Mirb.)Franco). Colloque Intl. sur la Culture "in vitro" des essences Forestitres. Fountainbleau, France. 